\title{
WATER QUALITY OF THE WATER PARK VALE DOS IPÊS IN CAMPOS GERAIS, MINAS GERAIS STATE.
}

\author{
POLYANNA ALVES SILVA ${ }^{1 *}$, \\ JUSSARA MARIA REIS CALIXTO ${ }^{3}$, \\ KEILA BATISTA LARA ROCHA ${ }^{2}$, \\ PATRÍCIA APARECIDA DA SILVA ${ }^{2}$, \\ POLIANA DE OLIVEIRA COELHO ${ }^{3}$ \\ ${ }^{1}$ Professora Doutora, FACICA, polyalves@gmail.com \\ ${ }^{2}$ Graduada em Ciências Biológicas, FACICA, keilacangere@yahoo.com.br; \\ ${ }^{3}$ Professora Mestre, FACICA, jussamare@ig.com.br; poliana@facica.edu.br. \\ *AUTORA CORRESPONDENTE: Dra. Polyanna Alves Silva \\ Endereço: Rua Simão Martins Ferreira, 64, centro. Campos Gerais, MG. Cep: 37160-000 \\ Email: polyalves@gmail.com \\ Recebido em: 10/10/2013 - Aprovado em: 18/12/2013 - Disponibilizado em: 15/01/2014

\begin{abstract}
This study evaluated some physico-chemical and microbiological parameters of water quality of the Water Park Vale dos Ipês in Campos Gerais, Minas Gerais State. Four water samples were taken at different sites during 3 consecutive weeks in October 2012. Four replicates of each collected sample were used for evaluations of $\mathrm{pH}$, turbidity and color and two replicates for microbiological analysis. Water quality was assessed based on that established by the Ordinance 518/2004 of the Ministry of Health. Water samples collected at the water park showed values of $\mathrm{pH}$, turbidity and color within the standards, but also high levels of coliforms at $35^{\circ} \mathrm{C}$ and thermotolerant thus not meeting the standards previously established by CONAMA. It is concluded that the analyzed water samples are not suitable for direct contact and for human food, nor suggested for irrigation of plants and vegetables. The analysis of the degree of contamination of the water park can be complemented with the development of research projects that can assess more specific parameters of contamination from industrial, agricultural and domestic effluents over a longer period of time.
\end{abstract}

Keywords: $35^{\circ} \mathrm{C}$ Coliform. Thermotolerant coliform. Physicochemical analysis. Microbiological analysis. Lake.

\section{QUALIDADE DA ÁGUA DO PARQUE AQUÁTICO VALE DOS IPÊS EM CAMPOS GERAIS, MG.}

\begin{abstract}
RESUMO: Este trabalho teve como objetivo avaliar alguns parâmetros de qualidade físico-química e microbiológica da água do parque aquático Vale dos Ipês em Campos Gerais, Minas Gerais. Foram coletadas 4 amostras de águas, em pontos diferentes, durante 3 semanas consecutivas do mês de outubro de 2012. Para as avaliações de pH, turbidez e cor foram utilizadas 4 repetições de cada amostra coletada e para as análises microbiológicas foram utilizadas 2 repetições. A qualidade da água foi avaliada baseando-se no que estabelece as normas da portaria 518/2004 do Ministério da Saúde. Os resultados obtidos para as análises físico-químicas demonstram que as amostras de água coletadas no parque aquático obtiveram valores de $\mathrm{pH}$, turbidez e cor dentro dos padrões e que apresentaram altos níveis de coliformes a $35^{\circ} \mathrm{C}$ e termotolerantes não atendendo aos padrões pré-estabelecidos pela CONAMA. Conclui-se que as amostras de água analisadas não são indicadas para contato direto e alimentação humana, não sendo também sugeridas para irrigações de plantas e hortaliças. O grau de contaminação das águas do parque aquático poderá ser complementado com o desenvolvimento de projetos de pesquisas que possam avaliar parâmetros mais específicos de contaminações de efluentes industriais, agrícolas e domésticos em um período maior de tempo.
\end{abstract}

Palavras-chave: Coliformes $35^{\circ} \mathrm{C}$. Coliformes termotolerantes. Análises físico-químicas. Análises microbiológicas. Lago.

192

Revista da Universidade Vale do Rio Verde, Três Corações, v. 11, n. 2, p. 192-199, ago./dez. 2013 


\section{INTRODUCTION}

Water is used by man for survival and its good quality favors the improvement of economic, social and community conditions, thus providing health and quality of life. It is an indispensable factor in the control and prevention of diseases and for hygiene. With regard to the economic importance, it represents an increase of average life of the population served, decreased mortality and reduced the number of hours lost to various diseases, which implies an increase in the number of hours worked by members of a community, and, thus, increased production.

Its multiple uses serve to wide range of human activities, standing out among others, public and industrial supply, agricultural irrigation, the production of electricity and leisure and recreational activities, and the preservation of aquatic life. However, water is also a major receiver of materials and waste, and can concentrate large amounts of microorganisms and cause damages due to liquid, organic or chemical waste which may be found in tourist sites. Various environmental impacts can also be observed, such as the use of pesticides, siltation, reduced marginal vegetation, tourist visits, and others.

The municipality of Campos Gerais, Southern Minas Gerais State, is part of the region bathed by the Furnas Dam whose waters have great impact on the economy, the leisure and health. The city has several tourist attractions such as the Serra do Paraíso and its waterfalls, Cristo Redentor and also the Water

Park Vale dos Ipês, seen as an attractive place for recreation, sports and tourism practices. In this last place is focused the present study, which aims at developing physical-chemical and microbiological analysis of the lake water belonging to this park, in order to gather data that can ensure the hygienic and sanitary quality.

\section{MATERIAL AND METHODS}

\section{Characterizatiion of the study}

A presente pesquisa teve como base metodológica pesquisas científicas quantitativas e qualitativas que utilizaram amostras de água do Lago do Parque Aquático Vale dos Ipês, proveniente da cidade de Campos Gerais - Minas Gerais.

\section{Description of the area}

The Water Park Vale dos Ipês, in the municipality of Campos Gerais, Southern Minas Gerais State, is located between the geographical coordinates $21^{\circ} 24^{\prime} 06^{\prime \prime} \mathrm{S}$ latitude and $45^{\circ} 45^{\prime} 31^{\prime \prime} \mathrm{W}$ longitude, having as neighboring cities, Boa Esperança and Campos do Meio to the north, Santana da Vargem and Três Pontas to the east, Paraguaçu and Fama to the south and Alfenas to the west. It belongs to the microregion of Varginha, forming along with other cities the Water Circuit, which comprises the entire complex of the Furnas Dam. The municipality consists of a central city of a district and several villages scattered in a rural landscape, 
with undulating topography, covered by a current vegetation of the type anthropogenic field, supplied hydrologically by the Grande River that belongs to the Paraná River basin. It has a population of approximately 27,600 inhabitants, according to IBGE (2010).

The park is between urban and rural areas, with low vegetation diversity, inserted without prior study and reforestation techniques.

The water that feeds the lake rises out in the Serra dos Macacos and was dammed at the first street which gives access to the bairro Presépio and to the bairro do Baixão. Earlier in that locality passed the sewage interceptors that begin to capture the sewers of the bairro Cidade Nova. This is why it can be seen rounded structures, which are exactly the places that give access to interceptors that are submerged, where excess water from the lake is drained by the collection system near the landfill and runs its natural course which is the boundary stream.

\section{Sampling}

Four water samples were analyzed, with 4 replicates each, for microbiological analysis were used 2 replicates. Samplings were conducted every Monday by the morning (8:00 am) for 3 consecutive weeks in October 2012. Samples were collected randomly and placed in coolers with ice packs, according to rules of the Manual of collections of VQÁguaPR (GIANOTO and BILATTO, 2005).

The handling of vials and collection of samples was carried out with the use of gloves to prevent contamination. Water quality was assessed by means of physicochemical and microbiological analysis, based on the Ordinance 518/2004 of the Ministry of Health. Analyses were performed in the Laboratory of Chemistry and Microbiology of Facica.

Figure 1 - Sampling sites of water collection. A: Site 1; B: Site 2; C: Site 3; D: Site 4.

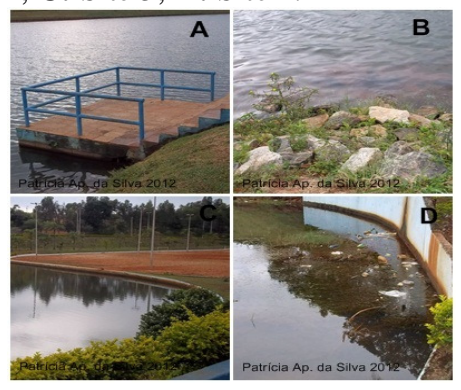

SOURCE - Patrícia Aparecida da Silva, 2012

\section{Determination of physical, chemical and microbiological parameters}

\section{Physical parameters}

Color

The color was determined by reading the apparent color in spectrophotometer at $425 \mathrm{~nm}$ and the results expressed in $\mathrm{uH}$ (Hazen unit - platinum - cobalt standard), according to the methodology of the American Public Health Association, described in the Standard methods for the examination of water and wastewater (2012). 


\section{Turbidity}

The determination of turbidity was taken by the nephelometric method, adopted in the activities for water pollution control and for verification of the physical parameter in waters considered potable. The method is based on comparing the intensity of light scattered by the sample under defined conditions with the light intensity scattered by a standard suspension. The turbidimeter is the apparatus used for reading, this apparatus consists of a nephelometer, and the turbidity is expressed in Jackson units or nephelometric turbidity units (NTU), according to the method described by Macedo (2001).

\section{Chemical parameter}

pH

The $\mathrm{pH}$ was determined by potentiometry in a glass electrode using a Digital QUIMIS $\mathrm{pH}$ meter, according to AOAC (2005). The $\mathrm{pH}$ is a very important parameter since it indicates the acidity or alkalinity of solutions. Through it we can have an idea of the quality of industrial waste released into the water (Macedo, 2001).

\section{Microbiological parameters}

The enumeration of coliforms at $35^{\circ} \mathrm{C}$ and thermotolerant coliforms were performed by using the most probable number method (MPN/100mL) of the American Public Health Association, described in Standard methods for the examination of water and wastewater

\section{Coliforms at $35^{\circ} \mathrm{C}$ (total)}

It was pipetted $3 \mathrm{ml}$ sample and added $1 \mathrm{ml}$ in their respective tubes of lauryl broth, constituting a direct inoculation (without dilution). $1 \mathrm{ml}$ was pipetted from the first sample to the first tube $\left(10^{-1}\right)$ with $9 \mathrm{~mL} 0.1 \%$ peptone water; $1 \mathrm{ml}$ of this solution was placed in the second tube $\left(10^{-2}\right)$ and so on until dilution $10^{-7}$. For each dilution were used three tubes of lauryl sulfate tryptose broth (LST) to inoculate. It was pipetted $3 \mathrm{~mL}$ of the tube with the highest dilution and $1 \mathrm{~mL}$ was placed in their corresponding LST broth. The procedure was repeated until the $10^{-7}$ dilution tubes. After the process, the inoculated tubes were stored in a culture oven for 48 hours at $35^{\circ} \mathrm{C}$, and then read. Tubes with turbid medium (acid formation) and bubbles inside the Durhan tube $\left(\mathrm{CO}_{2}\right)$ were considered positive for coliforms at $35^{\circ} \mathrm{C}$ (total). Any other option was interpreted as negative. The quantitation was performed by the table of Most Probable Number (MPN) in $100 \mathrm{~mL}$ sample, and the last dilution should have at least one negative tube.

\section{Thermotolerant coliforms}

From the tubes positive for coliforms at $35^{\circ} \mathrm{C}$ (total) was stabbed for the Escherichia coli broth (EC) tubes with the aid of a platinum loop, always flamed. Tubes were incubated in a water bath for 48 hours at $44.5^{\circ} \mathrm{C}$. The quantitation was performed by the table of Most Probable Number (MPN) in (2012). 
$100 \mathrm{~mL}$ sample, and the last dilution should have at least one negative tube

\section{RESULTS AND DISCUSSION}

Turbidity represents the degree of interference with the passage of light through the water, providing a turbid appearance. Particles responsible for turbidity are suspended solids, those of natural origin are rock particles (silt and clay), algae and microorganisms (BOTELHO, 2001). Table 1 shows that in the $1^{\text {st }}$ and $2^{\text {nd }}$ weeks there was no change in turbidity values (1.00 NTU) in sites $1,2,3$ and 4 . In the $3^{\text {rd }}$ week there was variation in all samples, with the highest value in the site 1 (2.95 NTU) and the lowest in the site 2 (2.45 NTU). Comparing our results to the standards established for Class 1 (40.0 NTU), 2 (100.0 NTU) and 3 (100.0 NTU), the values obtained are within the standards allowed for water bodies according to CONAMA (2005). Class 4 does not have any specific value for turbidity.

Table 1 - Mean values of turbidity (NTU) of the water of the Water Park Vale dos Ipês, Campos Gerais, Minas Gerais State.

\begin{tabular}{cccc}
\hline Sample & $\mathbf{1}^{\text {st }}$ week & $\mathbf{2}^{\text {nd }}$ week & $\mathbf{3}^{\text {rd }}$ week \\
\hline Site 1 & 1.00 & 1.00 & 2.95 \\
Site 2 & 1.00 & 1.00 & 2.45 \\
Site 3 & 1.00 & 1.00 & 2.71 \\
Site 4 & 1.00 & 1.00 & 2.68 \\
\hline
\end{tabular}

SOURCE - Chemistry Laboratory - FACICA 2012.

Sperling (2005) evaluated the water quality during the formation of deep lakes in mining pits of the lake of Águas Claras, Minas Gerais State, and found mean values of
8.0 NTU for samples collected at the surface and 12.0 NTU for samples collected in depth. The values observed herein work are lower than registered by Sperling (2005), but all the results are well below the limits allowed for classes 1 (40.0 NTU), 2 (100 UNT) and 3 (100 UNT) according to the CONAMA Resolution (2005).

The $\mathrm{pH}$ represents the concentration of hydrogen ions $\left(\mathrm{H}^{+}\right)$, indicating the condition of acidity, neutrality or alkalinity of the water (BOTELHO, 2001).

Table 2 - Mean values of $\mathrm{pH}$ of the water of the Water Park Vale dos Ipês, Campos Gerais, Minas Gerais State.

\begin{tabular}{cccc}
\hline Sample & $\mathbf{1}^{\text {st }}$ week & $\mathbf{2}^{\text {nd }}$ week & $\mathbf{3}^{\text {rd }}$ week \\
\hline Site 1 & 7.30 & 7.40 & 7.90 \\
Site 2 & 7.40 & 7.64 & 8.00 \\
Site 3 & 7.40 & 7.41 & 7.82 \\
Site 4 & 7.41 & 7.44 & 7.92 \\
\hline SOURCE - Chem
\end{tabular}

SOURCE - Chemistry Laboratory - FACICA 2012.

As shown in Table 2, mean $\mathrm{pH}$ values varied during the 3 weeks and in all analyzed sites. In the $1^{\text {st }}$ week, $\mathrm{pH}$ values were nearly equal, with the site 1 presenting the lowest value (7.30) and the site 4, the highest (7.41). In the $2^{\text {nd }}$ week, $\mathrm{pH}$ values varied, the lowest values verified in the site 1 (7.40), and the highest in the site 2 (7.64). In the $3^{\text {rd }}$ week, values were much higher than in the $1^{\text {st }}$ and $2^{\text {nd }}$ weeks, the site 3 had the lowest result (7.82) and the site 2 the highest value (8.00). Analyzing the three weeks, the lowest $\mathrm{pH}$ value was detected in the $1^{\text {st }}$ week in the site 1 with a value of 7.30 , and the highest $\mathrm{pH}$ value in the $3^{\text {rd }}$ week in the site $2,8.00$.

According to CONAMA (2005), the $\mathrm{pH}$ of the water of the Water Park Vale dos 
Ipês is in basic conditions with $\mathrm{pH}>7$. As standards established for water bodies, the $\mathrm{pH}$ values for all classes comprise 6.0 to 9.0 and the results of this work are ranging from 7.30 to 8.00 , confirming that they are within the limits.

Rodrigues et al. (2009) analyzing the physical, chemical and biological parameters in the municipal lake of Ipaussu, São Paulo State, found mean values of $\mathrm{pH}$ ranging from 8.3 to 7.2 , where 8.3 occurred on the right bank, while at the upper bank and in the middle the $\mathrm{pH}$ remained between 7.6 and 7.7 and close to the central region of the lake, 7.2. The values verified in the present study are close those of Rodrigues et al. (2009), and all results are within the limits allowed for all classes of water according to the CONAMA Resolution (2005).

The color is responsible for the coloring of water. Soluble solids are the responsible for the color of the water. Thus, its natural origin is the decay of organic matter (mainly - humic and fulvic acids), iron and manganese.

Table 3 - Mean values of color $(\mathrm{uH})$ of the water of the Water Park Vale dos Ipês, Campos Gerais, Minas Gerais State.

\begin{tabular}{cccc}
\hline Sample & $\mathbf{1}^{\text {st }}$ week & $\mathbf{2}^{\text {nd }}$ week & $\mathbf{3}^{\text {rd }}$ week \\
\hline Site 1 & 0.20 & 0.29 & 0.27 \\
Site 2 & 0.20 & 0.26 & 0.16 \\
Site 3 & 0.21 & 0.33 & 0.19 \\
Site 4 & 0.26 & 0.34 & 0.15 \\
\hline
\end{tabular}

SOURCE - Chemistry Laboratory - FACICA 2012.

In accordance with Table 3, there were variations in mean values of color within 3 weeks of analysis. In the $1^{\text {st }}$ week, the lowest values were found in the sites 1 and $2(0.20$
$\mathrm{uH})$ followed by the site $3(0.21 \mathrm{uH})$ and the highest in the site $4(0.26 \mathrm{uH})$. In the $2^{\text {nd }}$ week, the site 2 had the lowest value $(0.26$ $\mathrm{uH})$ and the site 4 , the highest $(0.34 \mathrm{uH})$. In the $3^{\text {rd }}$ week, the lowest value was found in the site 4 , with $0.15 \mathrm{uH}$, and the highest in the site $1,0.27 \mathrm{uH}$. Analyzing the three weeks together, the lowest value was obtained in the $3^{\text {rd }}$ week, in the site 4 , with $0.15 \mathrm{nH}$, and the highest value in the $2^{\text {nd }}$ week, also in the site 4, with $0.34 \mathrm{uH}$. In accordance with the standards for water bodies (CONAMA, 2005), the results of this work are within the limits established for Class $1(30 \mathrm{uH})$, for Class $2(75 \mathrm{uH})$ and class $3(75 \mathrm{uH})$. Class 4 has no limits set for the color parameter.

Organisms indicating faecal contamination show the extent of water contamination by human or animal feces, and therefore its potential to transmit diseases (SPERLING, 2005).

Table 4 - Mean values of coliform counts at $35^{\circ} \mathrm{C}$ (total) (MPN/100mL) in the water of the Water Park Vale dos Ipês, Campos Gerais, Minas Gerais State.

\begin{tabular}{cccc}
\hline Sample & $\mathbf{1}^{\text {st }}$ week & $\mathbf{2}^{\text {nd }}$ week & $\mathbf{3}^{\text {rd }}$ week \\
\hline Site 1 & $15 \times 10^{3}$ & $110 \times 10^{4}$ & $4.5 \times 10^{4}$ \\
Site 2 & $7.5 \times 10^{3}$ & $110 \times 10^{4}$ & $14 \times 10^{4}$ \\
Site 3 & $40 \times 10^{3}$ & $2.5 \times 10^{4}$ & $11000 \times 10^{4}$ \\
Site 4 & $25 \times 10^{3}$ & $25 \times 10^{4}$ & $11000 \times 10^{4}$ \\
\hline SOURCE - Microbiology Laboratory - FACICA \\
2012.
\end{tabular}

As shown in Table 4, the mean values of coliforms at $35^{\circ} \mathrm{C}$ (total) showed variations in the 3 weeks and 4 sites analyzed. In the $1^{\text {st }}$ week, the lowest coliform count was in the site 2 with $7.5 \times 10^{3} \mathrm{MPN}$ and in the site 3, the highest with a value of $40 \times 10^{3}$ MPN. In the $2^{\text {nd }}$ week, the lowest concentration of 
coliforms was found in the site 3 , with $2.5 \times 10^{4} \mathrm{MPN}$, followed by the site $4\left(25 \times 10^{4}\right.$ MPN) and of sites 1 and 2 that presented higher values $\left(110 \times 10^{4} \mathrm{MPN}\right)$. In the $3^{\text {rd }}$ week, the lowest result was in the site 1 with $4.5 \times 10^{4} \mathrm{MPN}$, followed by the site $2\left(14 \times 10^{4}\right.$ MPN) and sites 3 and 4 with values of $11000 \times 10^{4}$ MPN. Comparing the results of 3 weeks in the 4 sites, the lowest count of coliforms at $35^{\circ} \mathrm{C}$ occurred in the $1^{\text {st }}$ week in the site 2 with $7.5 \times 10^{3} \mathrm{MPN}$ and the highest in the $3^{\text {rd }}$ week in the sites 3 and 4 , with a value of $1000 \times 10^{4}$ MPN. Among the 3 weeks, higher values of coliforms at $35^{\circ} \mathrm{C}$ were found in the $3^{\text {rd }}$ week, mainly in the sites 3 and 4 .

According to the standards for water bodies (CONAMA 2005), the results of this study are far above the limits allowed for Class 1 (1000 MPN/100mL) for Class $2(5000$ MPN/100mL) and Class 3 (20000 MPN $/ 100 \mathrm{~mL})$. Class 4 has no limits set for coliform count at $35^{\circ} \mathrm{C}$ (total).

Table 5 - Mean values of thermotolerant coliform counts (MPN/100mL) in the water of the Water Park Vale dos Ipês, Campos Gerais, Minas Gerais State.

\begin{tabular}{cccc}
\multicolumn{4}{c}{ ale dos Ipês, Campos Gerais, Minas Gerais State. } \\
\hline Sample & $\mathbf{1}^{\text {st }}$ week & $\mathbf{2}^{\text {nd }}$ week & $\mathbf{3}^{\text {rd }}$ week \\
\hline Site 1 & $9.5 \times 10^{3}$ & $4 \times 10^{4}$ & $2.5 \times 10^{4}$ \\
Site 2 & $4.5 \times 10^{3}$ & $4 \times 10^{4}$ & $0.002 \times 10^{4}$ \\
Site 3 & $3 \times 10^{3}$ & $0.16 \times 10^{4}$ & $2 \times 10^{4}$ \\
Site 4 & $0.25 \times 10^{3}$ & $25 \times 10^{4}$ & $2 \times 10^{4}$ \\
\hline SOURCE - Microbiology Laboratory - FACICA
\end{tabular}
2012.

Table 5 lists the mean values of thermotolerant coliform counts, in the $1 \mathrm{st}$ week, the lowest concentration was found in the site 4 with a value of $0.25 \times 10^{3} \mathrm{MPN}$ and the highest in the site 1 with $9.5 \times 10^{3}$ MPN. In the $2^{\text {nd }}$ week, the lowest result was in the site
3, $0.16 \times 10^{4} \mathrm{MPN}$, and the highest was observed in the site 4 with $25 \times 10^{4}$ MPN. In the $3^{\text {rd }}$ week, the lowest count was found in the site 2, with $0.002 \times 10^{4}$ MPN and the highest in the sites 3 and 4 with values of $2 \times 10^{4}$ MPN. Also, in the $3^{\text {rd }}$ week values of thermotolerant coliforms decreased in the 4 sites, when compared with the $1^{\text {st }}$ and $2^{\text {nd }}$ weeks. According to the standards for water bodies (CONAMA 2005), our results are far above the limits allowed for Class 1 (200 MPN/100mL), for Class 2 (1000 MPN $/ 100 \mathrm{~mL})$ and for Class 3 (4000 MPN $/ 100 \mathrm{~mL}$ ). Class 4 has no limits set for thermotolerant coliforms.

Buzanello et al. (2007) determined the concentration of coliforms at $35^{\circ} \mathrm{C}$ (total) and thermotolerant coliforms in the water of the Municipal Lake of Cascavel, Paraná State, and reported that $62.5 \%$ of the samples did not meet the standards for drinking water, which determines the absence of coliforms in any situation including wells, mines, springs, lakes among others.

\section{CONCLUSION}

The results obtained for the physicochemical analyses pointed out that the water samples collected at the Water Park Vale dos Ipês located in Campos Gerais, Minas Gerais, showed values of $\mathrm{pH}$, turbidity and color within the standards, but also high levels of coliforms at $35^{\circ} \mathrm{C}$ (total) and thermotolerant coliforms, thus not meeting the limits set by 
CONAMA. The water samples analyzed are not suitable for direct contact and for human food, nor indicated for irrigation of plants and vegetables.

The analysis of the degree of water contamination of the Water Park can be

\section{REFERENCES}

\section{AMERICAN PUBLIC HEALTH}

ASSOCIATION. Standard methods for the examination of water and wastewater. $22^{\circ}$ ed. Washington, DC, 2012. 1496p.

AOAC. Official Methods of Analysis. 18th Ed. Assoc. Anal. Chem., Arlington. VA. 2005.

BOTELHO, C. G; Qualidade da água para irrigação. vol. 1. Lavras: UFLA/FAEPE, 2001. 104p.

BUZANELLO E. B.; MARTINHAGO M. W.; ALMEIDA M. M.; PINTO F. G. S. Determinação de Coliformes Totais e Termotolerantes na Água do Lago Municipal de Cascavel. Nota Científica. Paraná. Julho/2007.

CONAMA - Conselho Nacional do Maio Ambiente. Resolução No. 357/2005 - Dispõe sobre a classificação dos corpos de água e diretrizes ambientais para o seu enquadramento, bem como estabelece as condições e padrões de lançamento de efluentes, e dá outras providências. CONAMA. Brasília/DF. 2005. Disponível em:

<http://www.mma.gov.br/port/conama/res/res 05/res35705.pdf>. Acesso em: 20, out 2012.

DONADIO, N.M.M.; GALBIATTI, J.A.; PAULA, R.C.de. Qualidade da água de nascentes com diferentes usos do solo na bacia hidrográfica do Córrego Rico, São complemented with the development of research projects that can evaluate more specific parameters of contamination from industrial, agricultural and domestic effluents over a longer period of time.

Paulo, Brasil. Revista de Engenharia Agrícola de Jaboticabal, Jaboticabal, SP. v.25, n.1, p. 119-124p, 2005.

GIANOTO, N.; BILATTO, M. A. Manual de Coleta de Amostras de Água para Exame Laboratorial - VQÁguaPR. Cadernos de Saúde Ambiental. Curitiba, Março, 2005.

IBGE. Instituto Brasileiro de Geografia e Estatística. Pesquisa Nacional de Saneamento Básico - (PNSB). 2002. Disponível em: http://www.ibge.gov.br. Acesso em 20 de outubro de 2012.

Macêdo JÁ. Águas \& Águas. São Paulo; editora Varela, 2001.

RODRIGUES, R.; BRITTO, Y. C. T. BATMETRIA E ANÁLISES DOS PARÂMETROS FISÍCOS - QUIMÍCOS E BIOLÓGICOS NO LAGO MUNICIPAL DE IPAUSSU. Departamento de Ciências Biológicas - Faculdades Integradas de Ourinhos-FIO/FEMM. São Paulo, 2009. 6-11 p.

SPERLING, M. V. Introdução à qualidade das águas e ao tratamento de esgotos. 3. ed. v. 1. 452p. Departamento de Engenharia Sanitária e Ambiental, Belo Horizonte, 2005. 